\title{
Fire Tests of Steel Columns Protected With Siliceous Aggregate Concrete
}

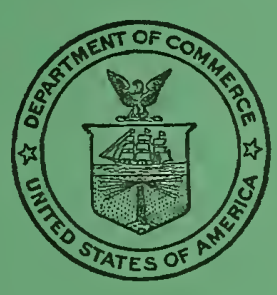

United States Department of Commerce National Bureau of Standards Building Materials and Structures Report 124 


\section{BUILDING MATERIALS AND STRUCTURES REPORTS}

On request, the Superintendent of Documents, U. S. Government Printing Office, Washington 25, D. C., will place your name on a special mailing list to receive notices of new reports in this series as soon as they are issued. There will be no charge for receiving such notices.

An alternative method is to deposit with the Superintendent of Documents the sum of $\$ 5$, with the request that the reports be sent to you as soon as issued, and that the cost thereof be charged against your deposit. This will provide for the mailing of the publications without delay. You will be notified when the amount of your deposit has become exhausted.

If 100 copies or more of any report are ordered at one time, a discount of 25 percent is allowed. Send all orders and remittances to the Superintendent of Documents, U. S. Government Printing Office, Washington 25, D. C.

The following publications in this series are available by purchase from the Superintendent of Documents at the prices indicated:

BMS1

BMS2

BMS3

BMS4

BMS5

BMS6

BMS7

BMS8

BMS9

BMS10

BMS11

BMS12

BMS13

BMS14

BMS15

BMS16

BMS17 Supplement to BMS17, Sound Insulation of Wall and Floor Constructions Supplement No. 2 to BMS17, Sound Insulation of Wall and Floor Constructions
BMS18 Structural Properties of "Pre-fab" Constructions for Walls, Partitions, and Floors

BMS19

BMS20

BMS21

BMS22

Research on Building Materials and Structures for Use in Low-Cost Housing -
Methods of Determining the Structural Properties of Low-Cost House Constructions.-

Suitability of Fiber Insulating Lath as a Plaster Base

Accelerated Aging of Fiber Building Boards

Structural Properties of Six Masonry Wall Constructions

Survey of Roofing Materials in the Southeastern States

Water Permeability of Masonry Walls

Methods of Investigation of Surface Treatment for Corrosion Protection of Steel

Structural Properties of the Insulated Steel Construction Co.'s "Frameless-Steel" Constructions for Walls, Partitions, Floors, and Roofs Sponsored by the H. H. Robertson Co

Structural Properties of the Curren Fabrihome Corporation's "Fabrihome" Constructions for Walls and Partitions

Structural Properties of "Steelox" Constructions for Walls, Partitions, Floors, and Roofs Sponsored by Steel Buildings, Inc

Properties of Some Fiber Building Boards of Current Manufacture.

Indentation and Recovery of Low-Cost Floor Coverings

Structural Properties of "Wheeling Long-Span Steel Floor" Construction Sponsored by the Wheeling Corrugating Co

Structural Properties of a "Tilecrete" Floor Construction Sponsored by Tilecrete

Floors, Inc Sponsored by the Harnischfeger Corporation Preparation and Revision of Building Codes Structural Properties of "Twachtman" Constructions for Walls and Floors Sponsored by Connecticut Pre-Cast Buildings Corporation Structural Properties of a Concrete-Block Cavity-Wail Construction Sponsored by the National Concrete Masonry Association
Structural Properties of "Dun-Ti-Stone" Wall Construction Sponsored by the W. E. Dunn Manufacturing Co Manufacturers Association of New York, Inc

BMS23

BMS24

BMS25

Structural Properties of a Reinforced-Brick Wall Construction and a Brick-Tile CavityWall Construction Sponsored by the Structural Clay Products Institute Structural Properties of Conventional Wood-Frame Constructions for Walls, Partitions, Floors, and Roofs "Nelson Pre-Cast Concrete Foundation" Wall Construction Sponsored by the Nelson Cement Stone Co., Inc.

BMS26

BMS27

BMS28

BMS29

BMS30

BMS31

Out of print † Superseded by BMS116. Bender Body Co of "Bender Steel Home" Wall Construction Sponsored by the Backflow Prevention in Over-Rim Water Supplies Survey of Roofing Materials in the Northeastern States Fir Plywood Association
Structural Properties of "Insulite", Wall and "Insulite" Partition Constructions Sponsored by The Insulite Co........... 


\title{
Fire Tests of Steel Columns Protected With Siliceous Aggregate Concrete
}

\author{
Nolan D. Mitchell
}

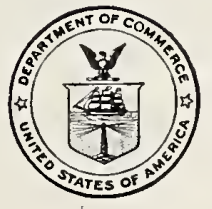

Building Materials and Structures Report 124

Issued May 25, 1951 



\section{Foreword}

This report, one of a series issued by the National Bureau of Standards on building materials and structures, presents the results of fire tests of four steel building columns protected by concrete made with certain highly siliceous aggregates. The results of the column tests were further confirmed by tests on concrete walls made with the same aggregates. Such materials are available in widely distributed areas, and are common constituents of nuch of the commercially available concretes.

The fire endurance limits of protected columns described in this report may serve as a guide for the selection of constructions to meet building code requirements, and as a measure of the extent of compliance of building practice with existing codes.

E. U. Condon, Director. 


\section{CONTENTS}

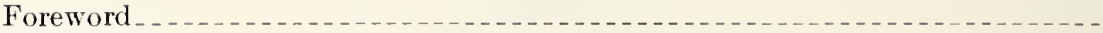

I. Introduction

II. Materials

1. Steel columins

2. Concrete

III. Construction of columns

1. Placement of concrete

2. Workmanship -

3. Seasoning of concrete.

IV. Equipment and method of testing

1. Equipment....-

2. Method of testing

(a) Bearing of columns

(b) Restraint of columns

(c) Loads on columns

(d) Measurement of deformations

(e) Test specification

V. Results of tests

1. Columns 1 and 2-Potomac River gravel aggregate concrete protections - -

2. Columns 3 and 4-Milky and clear quartz aggregate concrete protections.

VI. Summary and discussion. 


\title{
Fire Tests of Steel Columns Protected With Siliceous Aggregate Concrete
}

\author{
Nolan D. Mitchell
}

\begin{abstract}
Results of fire-endurance tests of four 6-in. steel $\mathrm{H}$-columns protected with concrete made with highly siliceous aggregates are presented. ${ }^{1}$ The concrete was of 2 -in. thickness around the column shaft and filled the reentrant spaces. The aggregates investigated were river gravel and crushed quartz.

The columns were subjected to load throughout the tests. The loads on three columns of magnitude as computed by a standard formula for allowable load were constant. One column sustained a double load throughout the earlier part of the test.

The fire-endurance limits ranged from 2 hr $50 \mathrm{~min}$ for a column with crushed quartz aggregate concrete to $3 \mathrm{hr} 34 \mathrm{~min}$ for one with gravel aggregate concrete. The results were consistent for columns protected with gravel aggregate concrete, and within reasonable limits for columns covered with quartz aggregate concrete.

The results of the column tests with respect to lack of spalling of the concrete were confirmed by tests on concrete wall slabs made with the same or like aggregates.
\end{abstract}

\section{Introduction}

Fire-endurance tests were conducted at the National Bureau of Standards on four 6-in. 20-lb $\mathrm{H}$-columns having protective coverings of siliceous aggregate concrete. The aggregate for the concrete on two columns was Potomac River sand and gravel, on the third crushed milky quartz, and on the fourth clear crushed quartz. These aggregates are widespread both in distribution and use and are available in the vicinity of Washington, D. C.

The information developed by these tests supplements that derived from the tests of columns with concrete coverings included in the series of tests conducted jointly by the Associated Factory Mutual Fire Insurance Companies, the National Board of Fire Underwriters, and the National Bureau of Standards, at Underwriters' Laboratories, Chicago, in 1917-18. ${ }^{2}$ Related through use of siliceous aggregates are the fire tests of concrete columns conducted at the former Pittsburgh testing station of the National Bureau of Standards. ${ }^{3}$

In the early tests, it was observed that column protections of concrete made with highly siliceous gravel aggregates cracked and spalled so as to expose the steel shaft or reinforcing of the column before its temperature had reached the critical range for failure under load. Further, siliceous aggregate concrete monolithic floors and walls showed varying and contradictory behavior in fire tests. To illustrate, a 6-in.-thick concrete

1 'Tbe term "siliceous" as used berein conforms to tbe usage in building codes in which it is construed to embrace tbe minerals composed wbolly or largely of quartz, cbert, flint, etc.

2 Fire tests of building columns, Underwriters' Laboratories, 1920; also publisbed as B. S. Tech. Pap. T184 (1921).

${ }^{3}$ Fire resistance of concrete columns by W. A. Hull and S. H. Ingberg, ${ }^{3}$ Fire resistance of concrete
B. S. Tech. Pap. T272 (1925), floor slab made with Potomac River gravel concrete began spalling within 35 min after the start of the fire-endurance test. At $1 \mathrm{hr} 45 \mathrm{~min}$ the fire had penetrated through a large hole formed in the spalled area. However, another floor specimen and three wall specimens made of concrete having aggregate from the same source showed no tendency to spall. The best surmise possible from the meager data was that the spalling could be due to the disruptive effect caused by superheating of water entrapped in the dense concrete.

The tests of columns at the National Bureau of Standards were for the purpose of again investigating the reaction of siliceous aggregate concretes to fire exposure, especially under the conditions of high stress peculiar to column encasements. To supplement the tests on the columns encased with siliceous aggregate concrete, results are given for four walls constructed of similar concretes. Three of these were made with Potomac River gravel and one with the crushed quartz that served as both the fine and coarse aggregates for the coverings of two of the four columns.

The columns, which were alike in size, were tested under an allowable load computed from a formula recommended by the American Institute of Steel Construction. However, as no tendency of the concrete to spall was evident in the first test, the second of the columns with gravel aggregate concrete protection was subjected to twice the load of the other columns until a specified temperature of the steel was attained to determine whether excessive strain would induce spalling of the encasement, after which the load was re- 
duced to that of the formula and maintained until failure had occurred.

The failure of silica gravel concrete protection observed early in the test at the Underwriters' Laboratories was not duplicated in the present tests. The fire-endurance limits for the columns of this series ranged from $2 \mathrm{hr} 50 \mathrm{~min}$ to $3 \mathrm{hr} 34$ min.

It should be noted that, although both groups of tests used concrete made with siliceous aggregates, there was dissimilarity in composition of the aggregates of the two groups. The aggregates of the concrete that failed earliest in the tests at the Underwriters' Laboratories contained 98 percent of chert, whereas the aggregate for the concrete used for the present tests consisted of either a mixture containing principally quartz, sandstone, and quartzite, with only a minor quantity of chert or a relatively pure crushed quartz. Also, despite the general assumption of poor performance of siliceous aggregate concretes, columns protected with this material have shown a reasonable resistance to fire. This is indicated by tests made at the Underwriters' Laboratories where an 8 in. column protected with 2 in. of sandstone concrete showed a fire-endurance limit exceeding $4 \mathrm{hr}$, even though considerable cracking and spalling of the concrete had occurred early in the test.

\section{Materials}

\section{Steel Columns}

The column shafts were fabricated from 6-in. 20-lb stanchion sections 5.97 in. $^{2}$ in area. The heads of the columns were restrained for 32 to 33 in. by $1 / 2$-in. plates of two types, leaving an effective column length of $124 \mathrm{in}$. End fittings were so applied as to allow the milled ends of the column

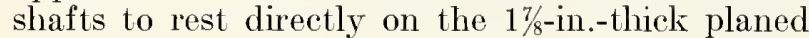
steel bearing plates. The column fitting assemblies were made with hot rivets. The least radius of gyration of the columns was $1.5 \mathrm{in}$. and the $l / r$ ratio was 82.67 . Figure 1 shows a column in place after a fire test. The details of the column shafts are shown in figure 2 .

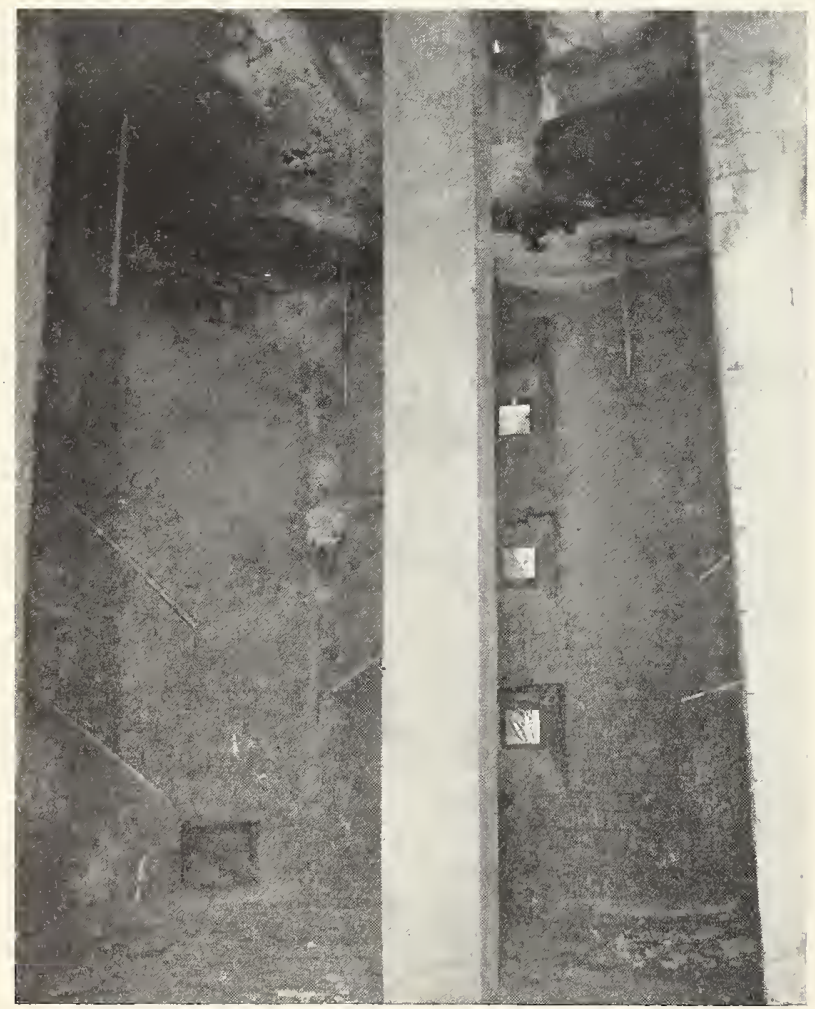

Figure 1. A test column in furnace after fire exposure.

\section{Concrete}

The concrete for encasing the first two columns of the tests was made of 1 part of portland cement, 21/2 parts of Potomac River concrete sand, and $31 / 2$ parts of Potomac River gravel. Equal parts of two sizes of screened gravel were mixed to produce the coarse aggregate. The densities of the sand and screened gravel were determined, and the batches were proportioned by weight of materials. A typical batch consisted of $94 \mathrm{lb}$ (1 bag) of cement, $300 \mathrm{lb}$ of damp sand, $197 \mathrm{lb}$ of fine gravel, $181 \mathrm{lb}$ of coarse gravel and $6 \frac{1}{2}$ gal water.

The sieve and petrographic analyses of the aggregates used in the concretes are shown in table 1 .

TABLE 1. Sieve and petrographic analyses of concrete aggregates

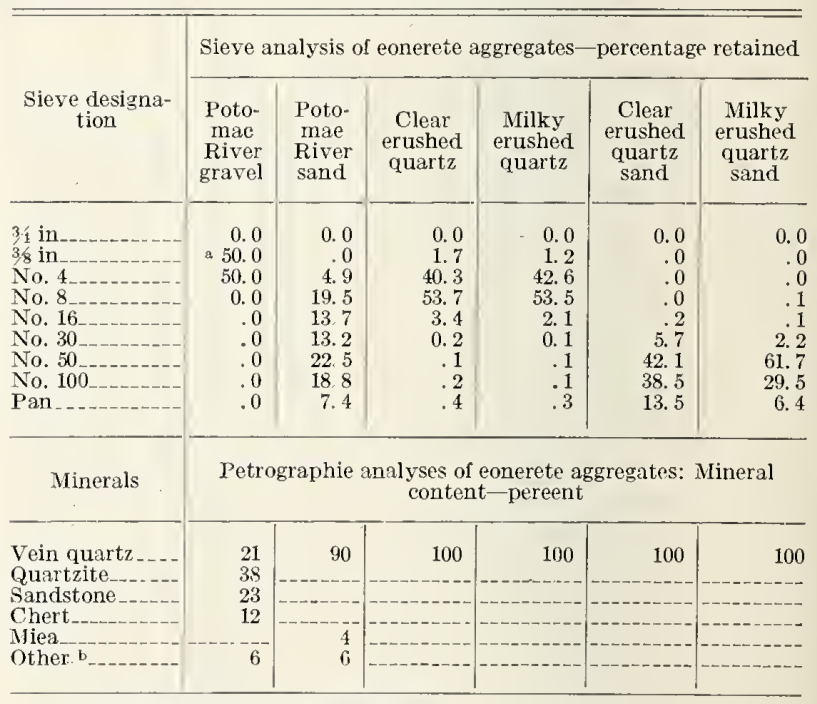

a Potomac River grarel sereened to size.

b One or more of the following: ehlorite, magnetite, sehist, gneiss.

In the tests, the third and fourth columns were covered with concrete made with fine and coarse aggregates of relatively high purity; that for one was of milky quartz, the other of a clear variety. Photomicrographs of these materials, figure 3 , 


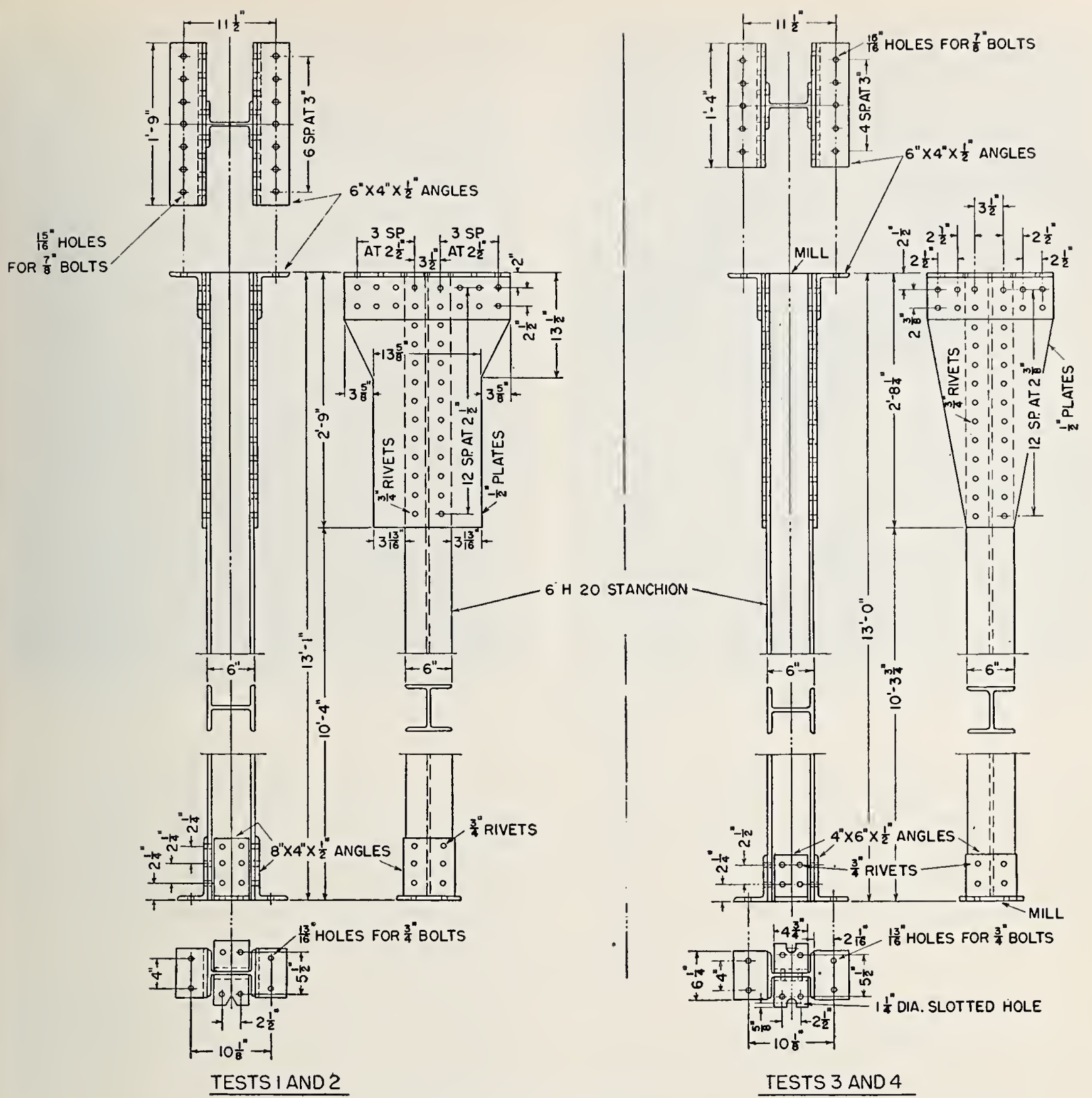

Figure 2. Details of columns.

show small inclusions. Because of the unusual grading of the coarse quartz aggregate, a workable mix was found to have the proportions approximately 1 part of cement, 3 parts of sand, and 2 parts of coarse aggregate. The batches were proportioned by weight and consisted of $94 \mathrm{lb}$ (1 bag) of cement, $293 \mathrm{lb}$ of quartz sand, and 195 lb of crushed quartz.

Each batch was mixed for not less than $1 \frac{1}{2}$ min dry and $2 \mathrm{~min}$ wet. Three test cylinders were cast from each of four batches of Potomac River aggregate concrete and three each from the single full batches of the milky and of the clear-quartz aggregate concretes. 'The water_was controlled to give slumps of concrete in the range of 6 to 8 in.

The average compressive strength of the cylinders of Potomac River gravel aggregate concrete was $2,580 \mathrm{lb} / \mathrm{in}^{2}$. The average batch strengths ranged from 2,240 to $2,800 \mathrm{lb} / \mathrm{in}^{2}$. The initial tangent modulus of elasticity of six cylinders was $2.97 \times 10^{6} \mathrm{lb} / \mathrm{in}^{2}$. The modulus determined from stress-strain relations at a working load of $1,600 \mathrm{lb} /$ in. $^{2}$ was $2.03 \times 10^{6} \mathrm{lb} / \mathrm{in}^{2}$.

For the concrete made with milky quartz aggregate, the average compressive strength of three cylinders was $1,930 \mathrm{lb} / \mathrm{in}^{2}$. The initial 

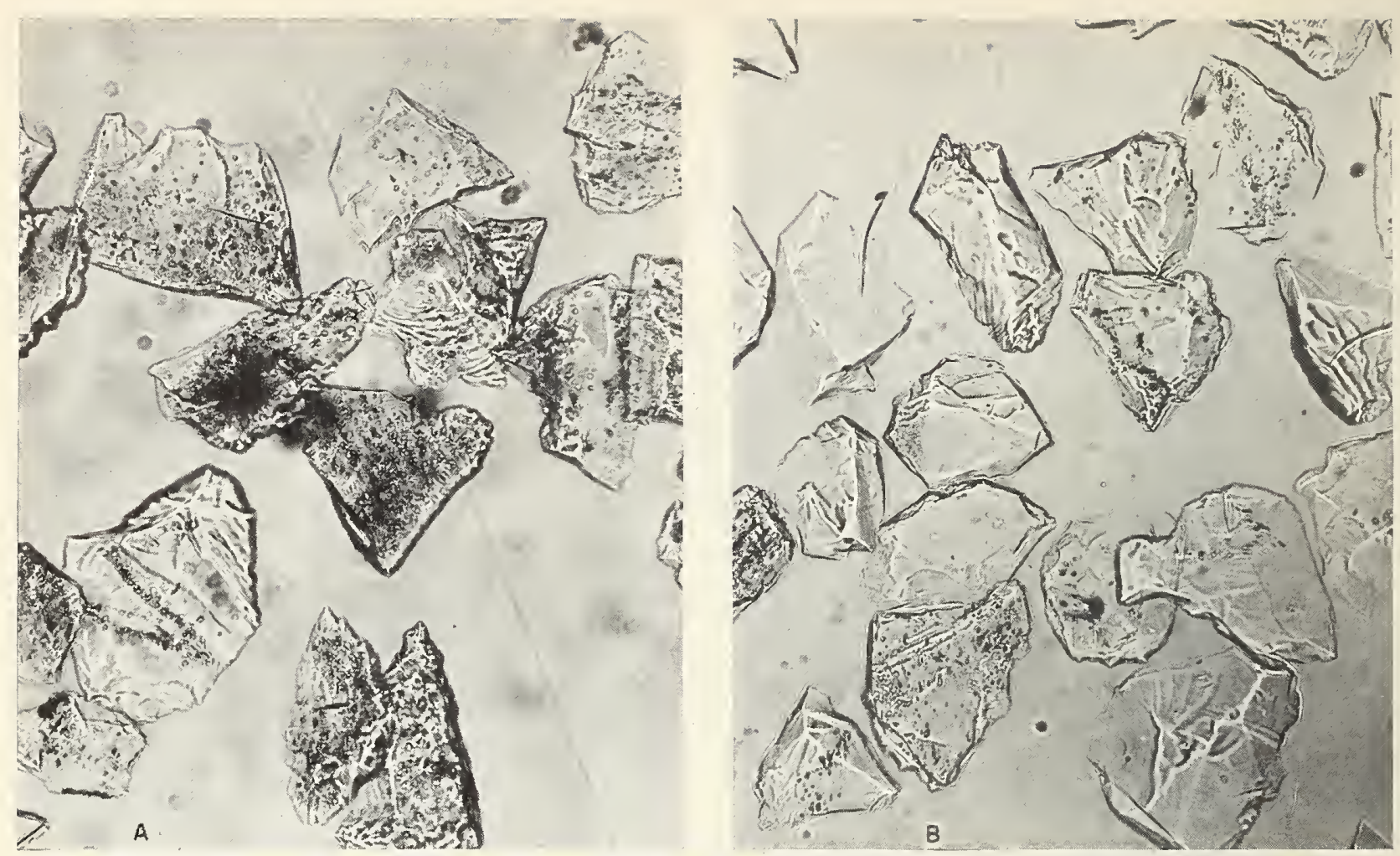

FIGURE 3. Photomicrographs of crushed quartz aggregates showing inclusions or voids (X96): A, milky; B, clear.

tangent elastic modulus as determined on one cylinder was $2.8 \times 10^{6} \mathrm{lb} / \mathrm{in}^{2}$. The three cylinders made with clcar quartz aggregate concrete had an average compressive strength of 2,600 $\mathrm{lb} / \mathrm{in}^{2}$. The modulus of elasticity for onc of these cylinders determined from the initial tangent was $2.6 \times 10^{6} \mathrm{lb} / \mathrm{in}^{2}$.

In all of the tests, a No. 8 SWG wire $(0.16 \mathrm{in.}$ in diameter) wound spirally around the column on an 8-in. pitch provided anchorage for the concrete covering. The wire spiral had 1-in. clearance at the midwidths of the column flanges, leaving a distance of $1 \mathrm{in}$. from the wire to the outside surface of the concrete. Thus the wire was covered with $1 \mathrm{in}$. of concretc at the midwidth of each of the four sides of the column.

\section{Construction of Columns}

\section{Placement of Concrete}

Plywood forms were spaced $2 \mathrm{in}$. on all sides from the vertically placed column shafts. Concrete poured into the tops of the forms was compacted around the columns by vibrating the sides of the forms with an air hammer. The few small voids, visible after the forms werc rcmoved, were filled with a cement and sand mortar.

A 4-by 8-ft. by 4-in.-thick wall slab was poured from the same batches of the clear and of the milky quartz aggregate concretes that were used for the column coverings. The slab was divided into quarters with the sections of like aggregate concrete diagonally opposite each other.

\section{Workmanship}

The steel columns were of good commercial quality of fabrication. The concrete was of ordinary good workmanship with a mixing time exceeding that of the prescribed minimum, and was well placed with the exception that the form around the enlarged portion of the top of one column was through inadvertence laterally displaced about 1 in. As this imperfection occurred in the upper restraincd portion of the column, well above the section under test, it was thought incapable of adversely affecting the results.

\section{Seasoning of Concrete}

The forms were stripped from the columns encased with Potomac River gravel concrete on the fifth day after pouring. The columns werc kept moist for 8 days. Beginning the ninth day after removal of forms, the weights of the columns were chccked until such time as drying was essentially complete. In 30 days, concrete that weighed approximately $2,900 \mathrm{lb}$ had lost $37 \mathrm{lb}$, after which its weight remained constant.

The column protections of crushed quartz aggregate concrete were allowed to remain in the forms 15 days, after which the concrete was kept moist 5 days. The concrete was further seasoned under atmospheric conditions for $2 \frac{1}{2}$ months prior to test. 


\section{Equipment and Method of Testing}

\section{Equipment}

The tests were made in gas-fired furnaces equipped with hydraulic jacks for applying load. The furnace, loading equipment, and the columis under test are shown in figure 4 . 'The furnace, while not originally designed for columns, was modified by an increase in height to accommodate a column having an cffective length of $124 \mathrm{in}$.

The jack piston was raised by an electrically driven oil pump equipped for automatic control of pressures. The movable floor of the furnace rested on a spherical bearing block raised and lowered by the hydraulic jack.

Temperatures at 12 locations in the furnace were measured with chromel-alumel thermocouples protected by iron tubes. The temperatures at 16 or more points on each column were also measured with similar thermocouples made of No. $18 \mathrm{AWG}$ wires. The thermocouple junctions were formed by inserting carefully cleaned ends of the respective wires into $1.1-\mathrm{mm}$ diameter paired holes spaced at $1 / 4 \mathrm{in}$. drilled into the column shaft. Steel was swaged around the holes to secure metalto-metal contact with the wires. The thermocouples were disposed at each of four levels of the column shafts as indicated by the positions $\mathrm{B}, \mathrm{N}$, $M$, and $\mathrm{T}$ in figure 4 .

\section{Method of Testing}

\section{(a) Bearing of Columns}

Steel bearing plates were bolted at either end of a test column. The plate at the bottom was 20 in. sq and $1 \frac{7 / 8}{}$ in. thick. The top plate, 25 by 27 by $17 / 8$ in. was fixed to the column with fourteen $7 / 8$-in. bolts $2 \frac{1}{2}$ in. long, and in turn was bolted to the overhead bearing of the loading frame of the furnace in such a position as to center the bottom plate over the loading jack. The furnace floor' was then raised to within $3 / 4$ in. of the bottom plate and the space between filled with portland cement grout. As the floor rested on a well-lubricated ball-and-socket joint coincident with the vertical center line of the column shaft, the column was considered to have a spherical end bearing at its lower extremity.

\section{(b) Restraint of Columns}

The plates attached to the head of a column were designed to give effective restraint against bending of the upper 33 in., thus offering substantially full continuity from the top of the fireexposed test portion of the column shaft to the overhead bearing.

\section{(c) Loads on Columns}

The load imposed during the test on three of the columns was computed from a formula for allowable load recommended by the American Institute of Steel Construction

$$
P=\left(17,000-0.485 \frac{l^{2}}{r^{2}}\right) A,
$$

in which $P=81,700 \mathrm{lb}$, total load on a column, equivalent to a stress of $13,700 \mathrm{lb} / \mathrm{in} .^{2}$ on the crosssectional area $A$ of the column $\left(5.97 \mathrm{in.}^{2}\right)$; $l=124$ in., the effective length of the column; $r=1.50$ in., the least radius of gyration of the steel column.

The load was applied before starting the test fire and was maintained until rapid yielding of the column occurred, the load being removed when the yield of a column from its maximum expansion amounted to approximately $0.6 \mathrm{in}$., or threefourths of the amount of its expansion.

The second of the columns protected with Potomac River gravel aggregate concrete was loaded to $163,000 \mathrm{lb}$ before the test, and this load was maintained until the average of the temperatures at 16 points in the steel reached $445^{\circ} \mathrm{C}$ $\left(833^{\circ} \mathrm{F}\right)$, the maximum at any of the 16 points being $490^{\circ} \mathrm{C}\left(914^{\circ} \mathrm{F}\right)$. These temperatures were attained in $1 \mathrm{hr} 51 \mathrm{~min}$ after the start of the test, at which time the load was reduced to that of the other tests.

\section{(d) Measurement of Deformations}

Movement of the piston of the hydraulic jack as observed on a dial indicator was taken as a measure of the longitudinal deformation of a column. Measurements made during previous tests indicated that the thermal expansion of the vertical framework was closely compensated by the expansion of the unexposed section of the column and the thermal deflections of the overhead beams supporting the upper bearing plate. No measurements of the lateral deflections of a column were made during or after a test.

\section{(e) Test Specification}

The tests werc conducted in accordance with the American Society for Testing Materials Standard Methods of Fire Tests of Building Construction and Materials, E119-41 (ASA No. 2.1-1942) as applicable to loaded columns. The loading schedule for one column, as previously described, deviated from that of the specification.

The limit of fire endurance was selected as the time from the start required to attain a vield of about 0.6 in. from the point of maximum expansion of a column. 


\section{Results of Tests}

\section{Columns 1 and 2-Potomac River Gravel Aggregate Concrete Protections}

The results of fire tests of columns protected with concrete made with Potomac River gravel aggregate are shown in figures 5 and 6 .

Figure 5 shows the temperatures within the furnace and the standard furnace reference curve. Also shown are the maximum observed temperatures at any thermocouple, the temperatures at the level having the highest average most consistently, and the minimum level temperatures in a column. The average of tcmperatures for the scveral levels are arithmetical. They were not weighted in proportion to the areas involved as were those reported in previous tests. ${ }^{4}$ It was considered that the greater temperature effects on the column strength at the edges of the flanges, as compared to the effects at the midpoint of the flange or web, compensated for the smaller crosssectional area contributory to each thermocouple near the edges.

The failure of both columns involved deformation throughout the fire-exposed lengths. The lateral deformation of column 1 was somewhat greater than that of column 2 and was centcred somewhat lower in the shaft. Although the lateral deflections were unequal, the total shortening of both columns, as detcrmined by measurements before and after the tests, was the same, $0.4 \mathrm{in}$.

The expansion of the columns with increases in the average temperatures of the steel shafts are shown in figure 6 . Column 2 was subjected to double the load applied to column 1 until the average temperature in the shaft reached $445^{\circ} \mathrm{C}$ $\left(883^{\circ} \mathrm{F}\right)$, after which the load was reduced to that of column 1.

Yielding of the steel under constant load with increasing temperature began in column 1 after the average temperature of the steel shaft had exceeded $570^{\circ} \mathrm{C}\left(1,058^{\circ} \mathrm{F}\right)$ and in column 2 after it had excecded $610^{\circ} \mathrm{C}\left(1,130^{\circ} \mathrm{F}\right)$. Endpoint temperatures for column 1 were $730^{\circ} \mathrm{C}$ $\left(1,346^{\circ} \mathrm{F}\right)$ as the average of all thermocouples and $775^{\circ} \mathrm{C}\left(1,427^{\circ} \mathrm{F}\right)$ maximum at one location; for column $2,725^{\circ} \mathrm{C}\left(1,337^{\circ} \mathrm{F}\right)$ was the averagc endpoint temperature and $760^{\circ} \mathrm{C}\left(1,400^{\circ} \mathrm{F}\right)$, the maximum at one location. The fire-endurance limit for column 1 was 3 hr $34 \mathrm{~min}$ and for column 2, 3 hr $32 \mathrm{~min}$.

The condition of the gravel aggregate concrete column protections after the fire test arc shown in figures 1 and 7 . Figure 8 shows the two columns after removal of the concrete encasement.

The Potomac River gravel concrete of three monolithic walls did not spall or develop serious cracks throughout the fire- and load-test pcriods. Two reinforced concrete walls 4 and 6 in. thick were exposed for $1 \mathrm{hr} 27 \mathrm{~min}$ and $4 \mathrm{hr}$, respectively. Figure 9 shows the fire-exposed face of an 8-in.

\footnotetext{
"Fire tests of building columns, Underwriter's' Labolatories 1920; also
} published as B. S. Tech. Pap. T184 (1921) unreinforced wall after $5 \frac{112}{2}$ lir test. These walls suffered only minor cracking and in no case was there evidence of spalling.

\section{Columns 3 and 4-Milky and Clear Quartz Aggregate Concrete Protections}

Figures 10 and 11 show the results of fire tests on steel columns protected with crushed quartz aggregate concrcte. Temperatures within the furnace and the standard reference curve are shown in figure 10 , as well as the observed temperature at any thermocouple in a column, the temperature at the level having the highest average most consistently, and the minimum average temperature at one level. As was true for the first two columns, the averages are arithmetical and not weighted.

Both columns suffered lateral deformations in their fire-cxposed portions. The concrete with milky quartz aggregate of column 3 showed only minor cracking at the end of the test, as is seen in figure 12. Failure to cease application of the load at the end of the test when the contraction had reached the predetermined value of $5 / 8$ in. caused severe bending of the shaft of column 4 . The clear quartz aggregate concrete showed little cracking and no evidence of spalling prior to the excessive deformation.

The expansion of the columns with increase in averagc temperature of the shafts is shown in figure 11. Yielding under constant load and increasing temperature began in column 3 at an average temperature of the steel of $525^{\circ} \mathrm{C}\left(977^{\circ} \mathrm{F}\right)$ and in column 4 at $535^{\circ} \mathrm{C}\left(995^{\circ} \mathrm{F}\right)$. End-point temperatures for column 3 at the fire-endurance limit of $3 \mathrm{hr} 10 \mathrm{~min}$ were $625^{\circ} \mathrm{C}\left(1,157^{\circ} \mathrm{F}\right)$ as the average of all thermocouples and $730^{\circ} \mathrm{C}\left(1,346^{\circ} \mathrm{F}\right)$ maximum at any onc thermocouple. For column 4 , the average end-point temperature was $620^{\circ} \mathrm{C}$ $\left(1,148^{\circ} \mathrm{F}\right)$ and the single point maximum was $755^{\circ}$ C $\left(1,391^{\circ} \mathrm{F}\right)$. The fire-endurance limit was $2 \mathrm{hr}$ $50 \mathrm{~min}$. A correction of $4 \mathrm{~min}$ may be added to the fire-endurance time of column 3 because of thc excess of the furnace exposure over the standard.

The quartz aggregate concrete of a 4 - by $8-\mathrm{ft}$ wall slab 4 in. thick showed only a fine crack in the line of a pouring joint after a fire exposure of $1 \frac{1}{2} \mathrm{hr}$. The slab was poured in quarters from the same milky and clear quartz concrete batches used for columns 3 and 4 , the sections with like aggregate being diagonally opposite. Figure 13 shows the fire-exposed face of the wall after removal from the furnace.

\section{Summary and Discussion}

The steel columns of these tests were of a type commonly used as structural members. The concrete protections were made with siliceous aggregates of widespread occurrence. The concrete used on columns 1 and 2 , made with a gravel 


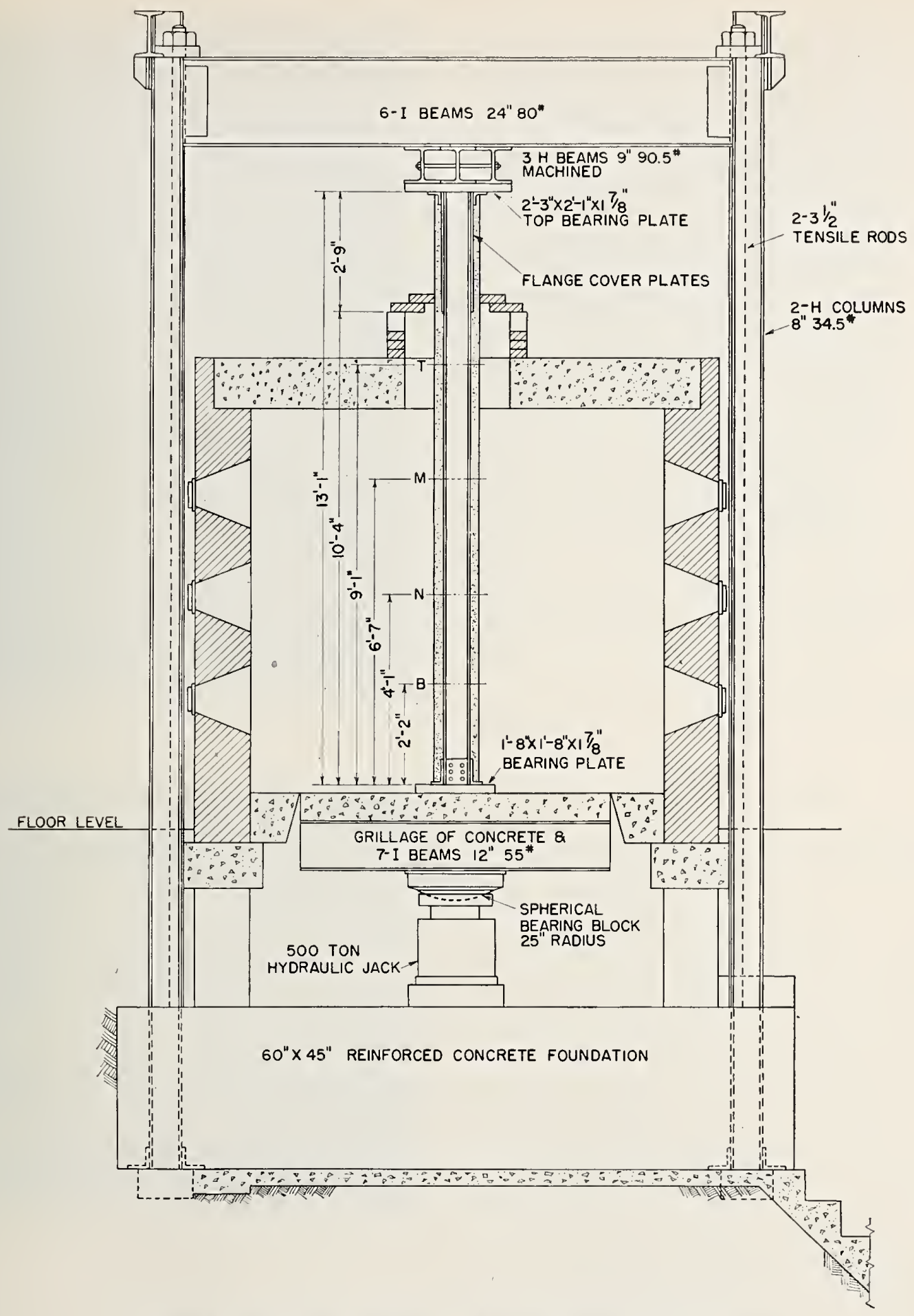

Figure 4. Furnace and loading equipment with typical column in place. 


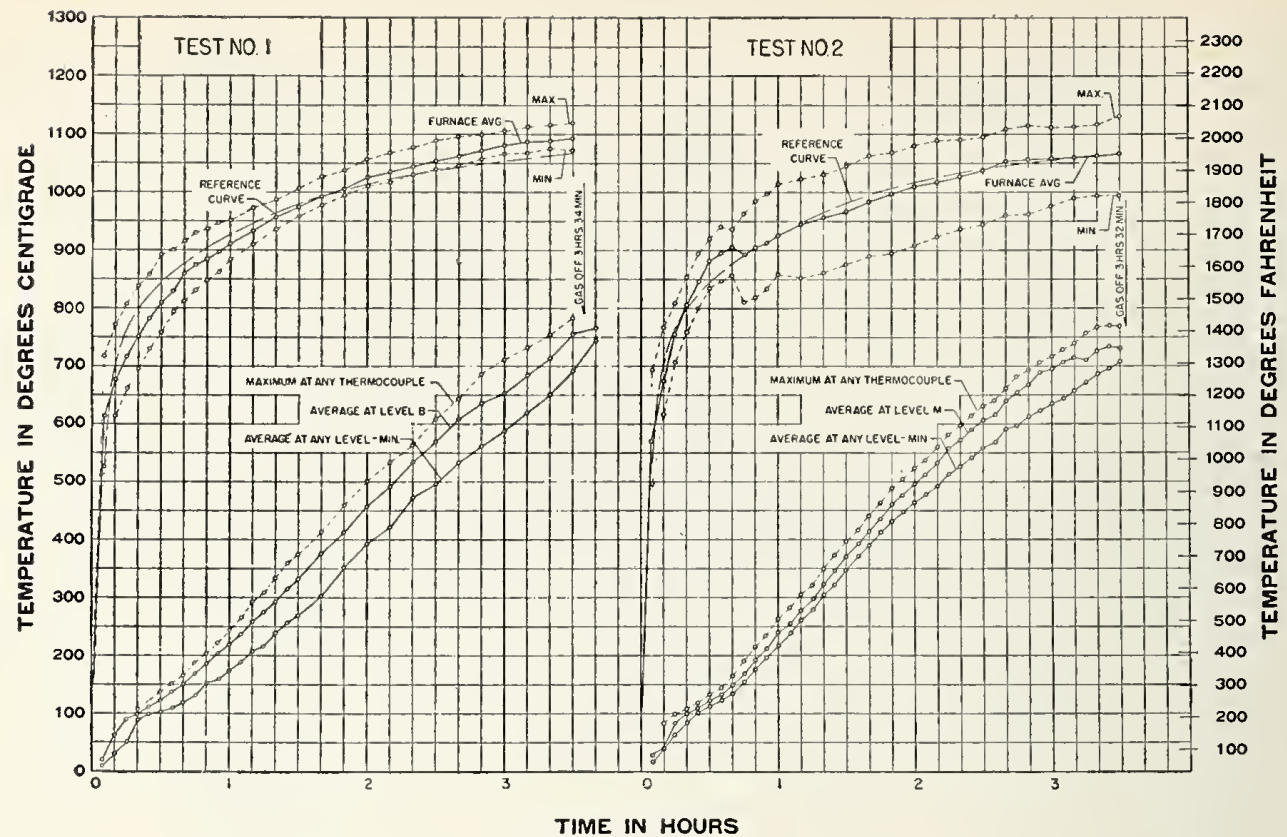

FigUre 5. Furnace and column tempcratures for columns with Potomae River gravel conerete-Tests 1 and 2.

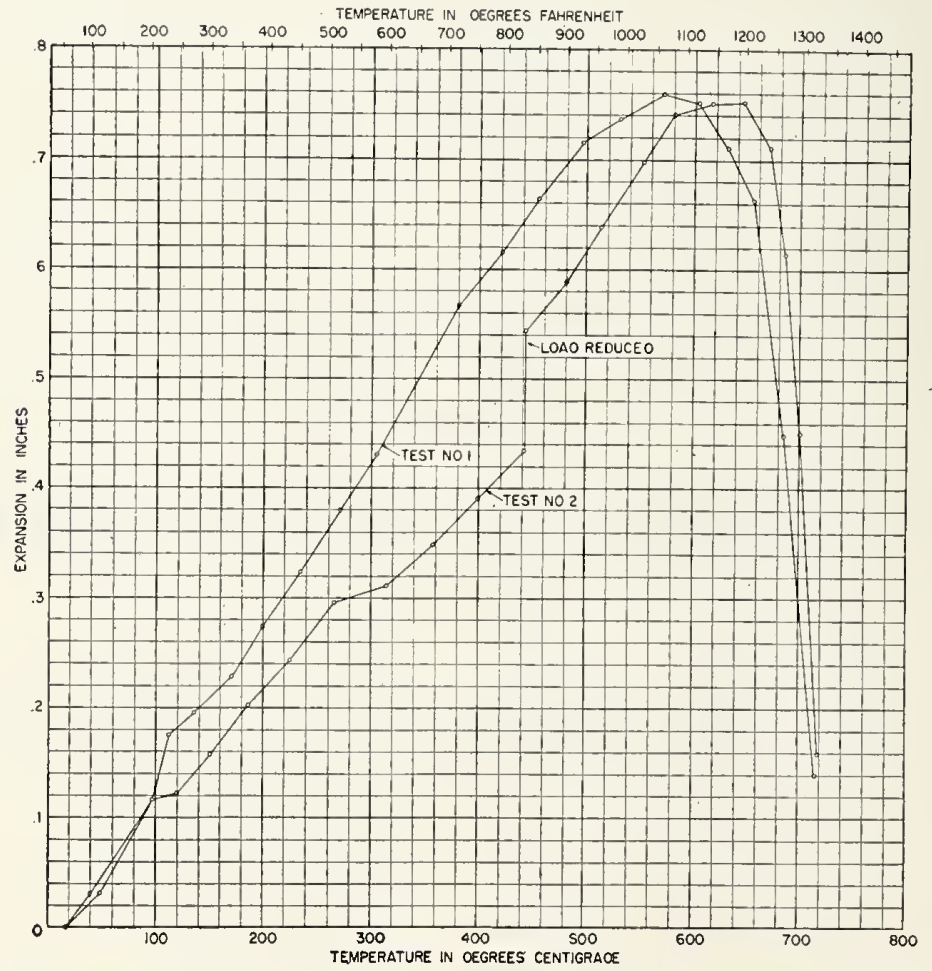

FIGURE 6. Expansion curves for eolumns with Potomac River gravel concrete-Tests 1 and 2. 


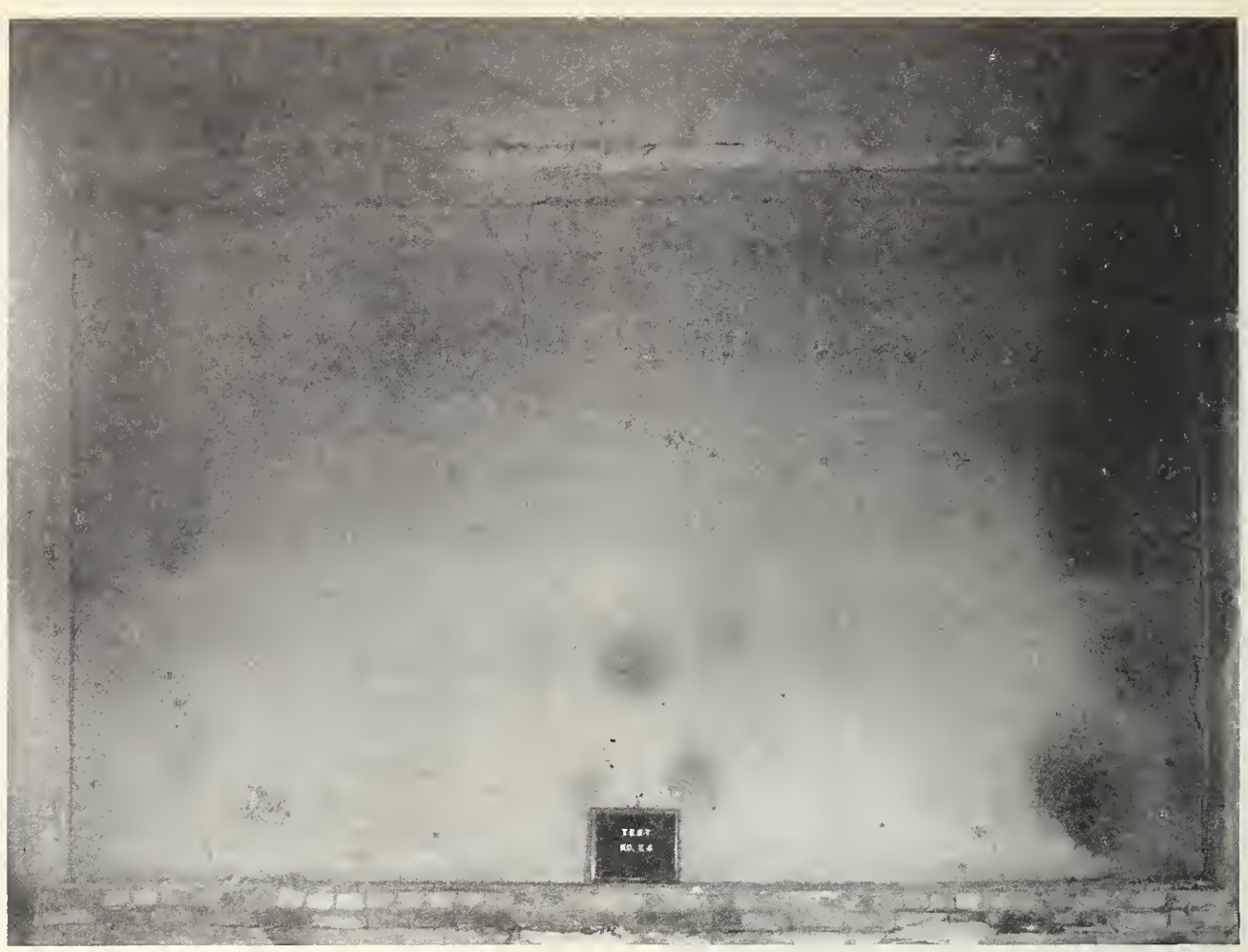

FIgURE 9. Fire-exposed face of an 8-in. unreinforced wall of Potomac River gravel concrete after 51/2-hr test.

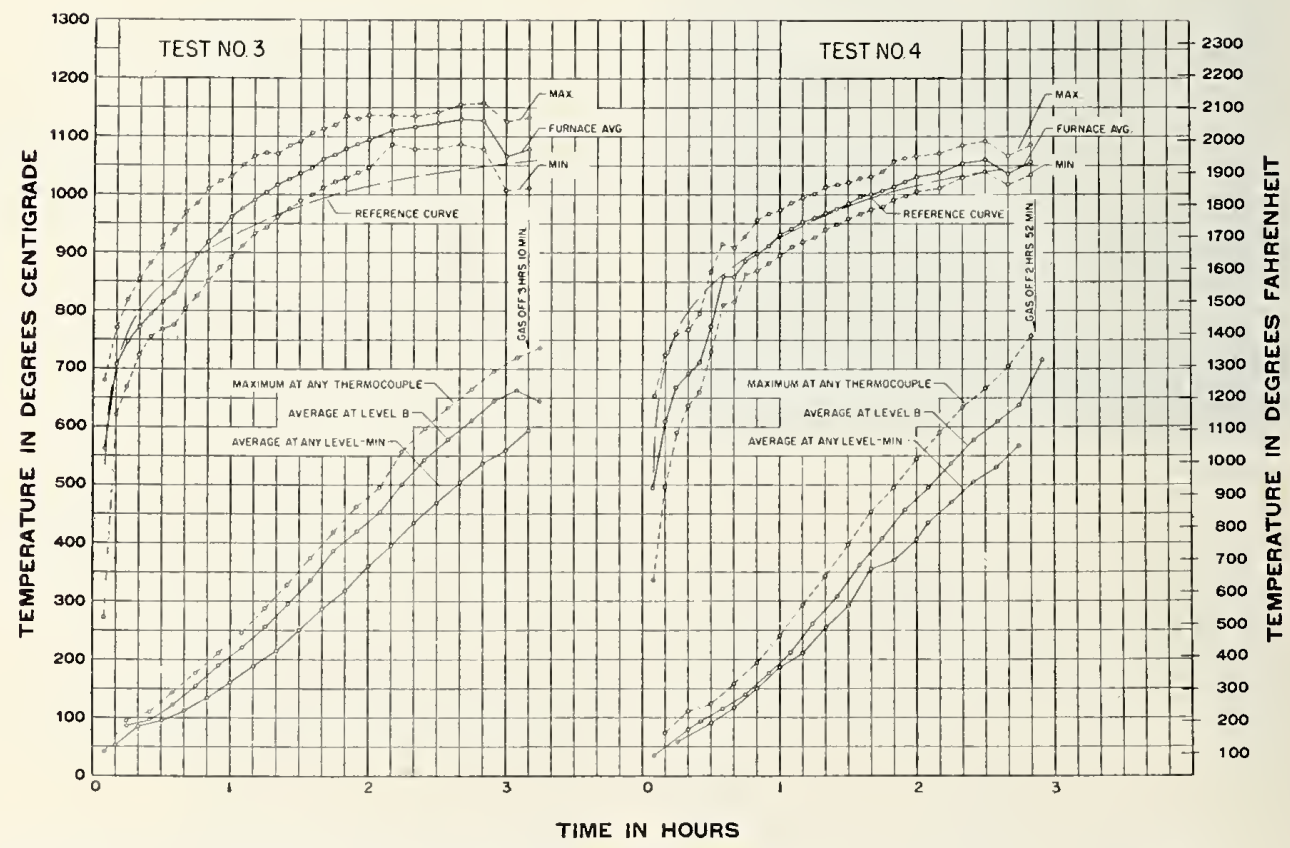

Figure 10. Furnace and column temperatures for columns with crushed quartz concrete-Tests 3 and 4. 


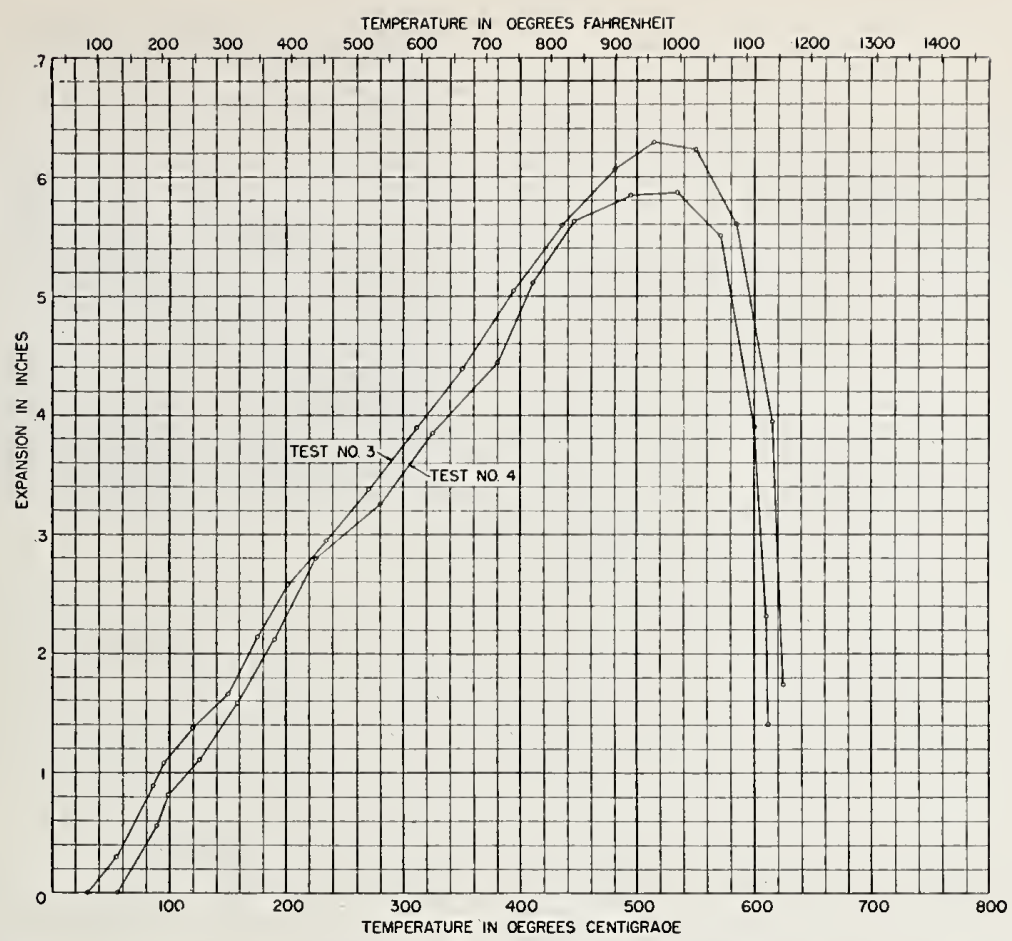

FiguRe 11. Expansion curves for columns with crushed quartz aggregate concrete-Tests 3 and 4.

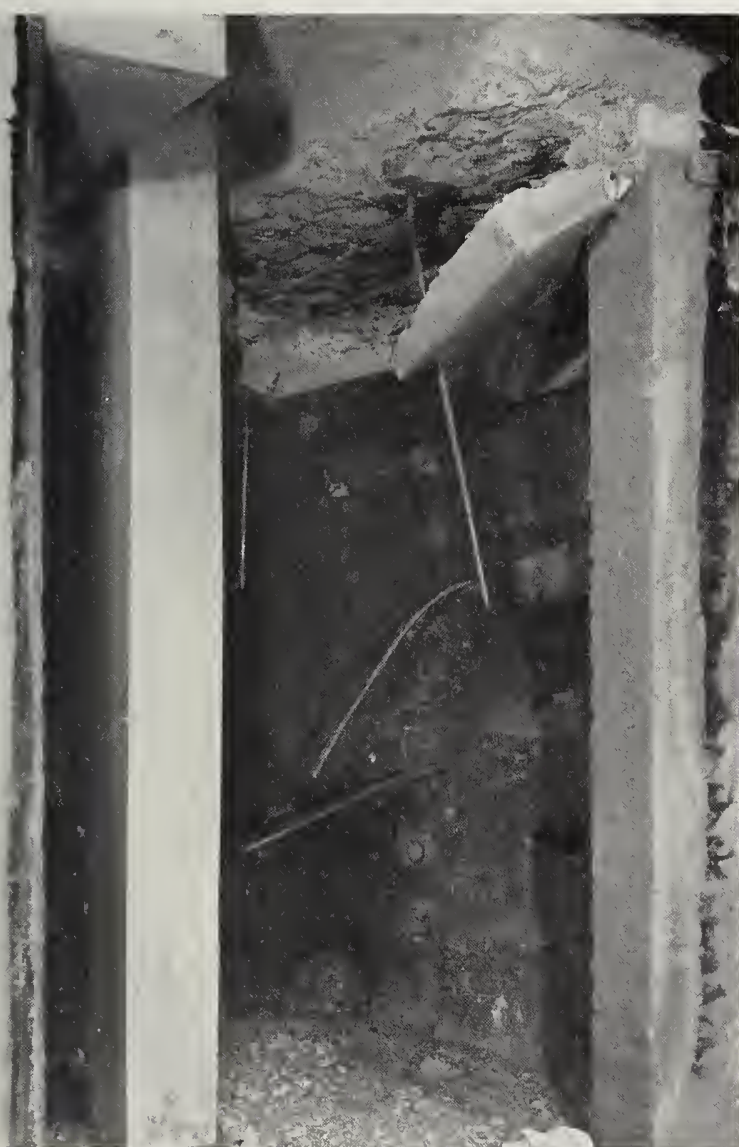

FIGURE 12. Column protected with milky quartz aggregate concrete after 3-hr 10-min fire exposure-Test 3.

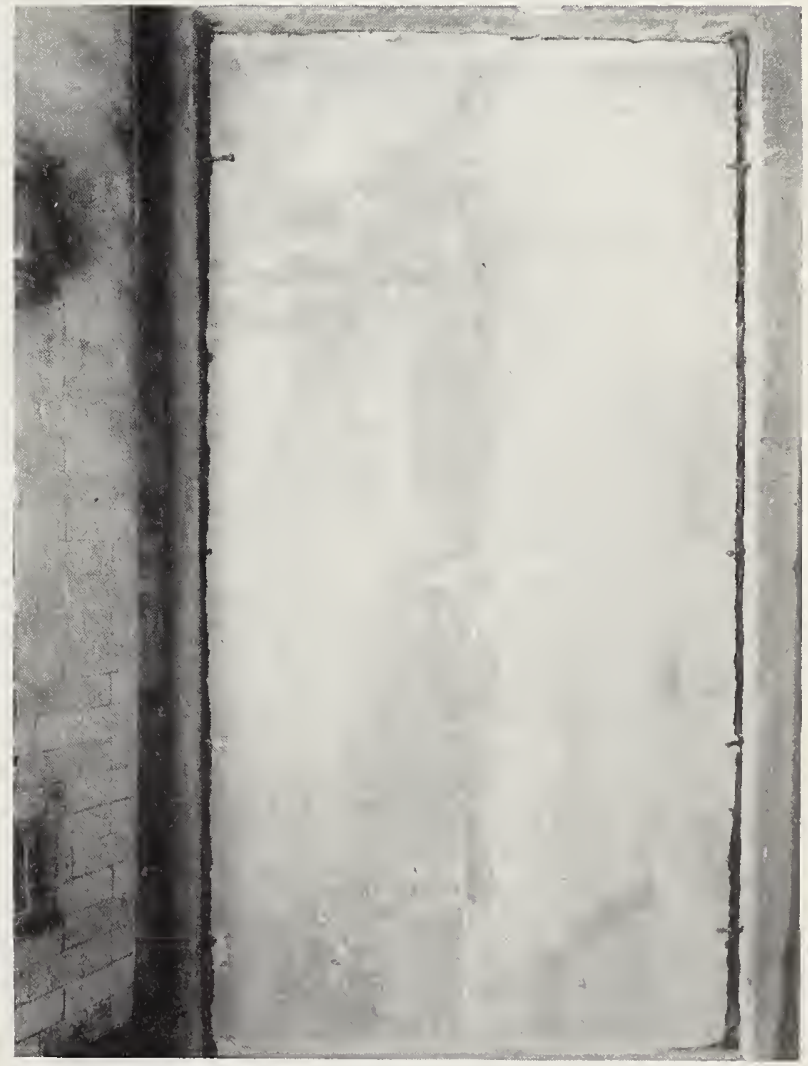

Figure 13. Fire-exposed face of a crushed quartz concrete wall slab after $1 \frac{1}{2}-$ hr test. 
TABLE 2. Derived fire-resistance ratings of steel shaft $\mathrm{H}$-columns with 2 inches of concrete protection

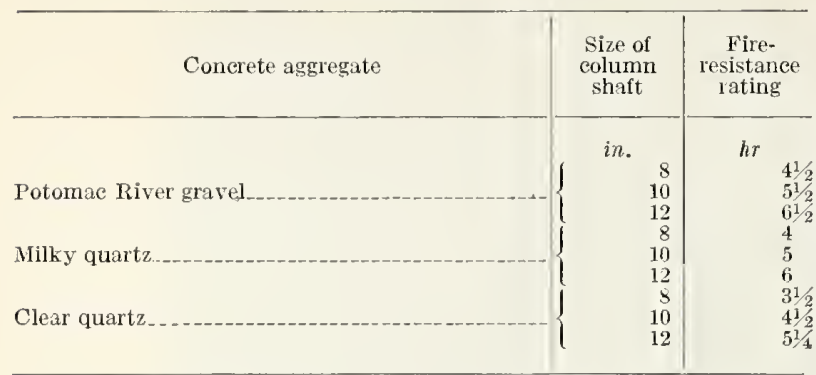

The resistance of a concrete to high temperatures is probably influenced by its density. The spalling caused by the explosion resulting from superheated water in a dense concrete was previously mentioned in connection with the failure of a floor slab made with siliceous aggregate concrete. Further evidence of this effect can be seen in figure 12 , which shows failure of the concrete top of the furnace after the first fire-endurance test to which the concrete was subjected. The failure occurred with explosive force $34 \mathrm{~min}$ after a 3 -hr 10 -min fire exposure, at which time the furnace still retained considerable heat. Examination of the debris showed the concrete, made with carefully graded firebrick aggregate, to be extremely compact. The structure of the spalled material can be seen in the photograph of the sample in figure 14 .

The aggregates used in both series of tests, while siliceous in character, differed in mineralogical composition. Those composed largely of chert

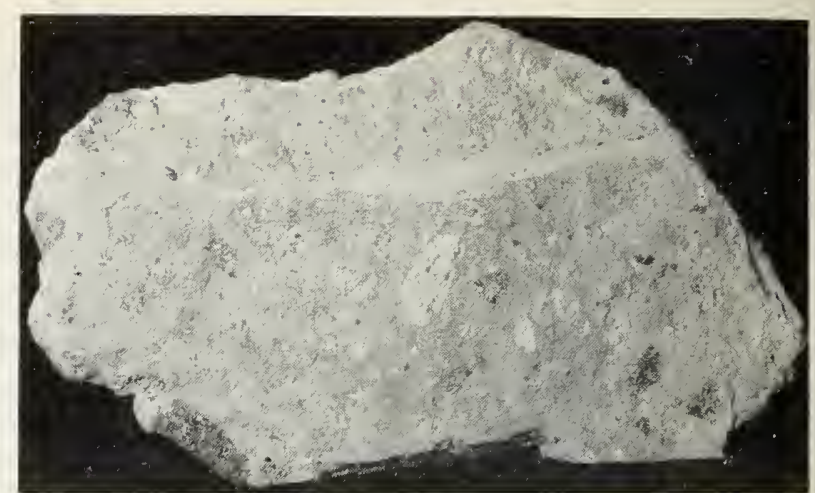

FIGURE 14. 'Sample of firebrick aggregate concrete spalled from top of furnace.

gave the poorest results in the tests at Underwriters' Laboratories. It is possible that an impurity or vaporizing water in the chert caused a disruptive force upon the application of heat. The characteristically rapid volume change of the siliceous minerals at critically high temperatures had no apparent effect upon the concrete used in the present tests.

The results of the tests indicate that concrete made with siliceous aggregates, as herein described, provides an acceptable material for the protection of structural steel against fire. The consistency of the results allowed definite conclusions as to the reliability of the protections for the demonstrated fire-endurance limits.

Washington, September 12, 1950. 


\section{BUILDING MATERIALS AND STRUCTURES REPORTS}

[Continued from cover page II]

BMS32

BMS33

BMS34

BMS35

BMS36

BMS37

BMS38

BMS39

BMS40

BMS41

BMS42

BMS43

BMS44

BMS45

BMS46

BMS47

BMS48

BMS49

BMS50

BMS51

BMS52

BMS53

BMS54

BMS55

BMS56

BMS57

BMS58

BMS59

BMS60

BMS61

BMS62

BMS63

BMS64

BMS65

BMS66

BMS67

BMS68

BMS69

BMS70

BMS71

BMS72

BMS73

BMS74

BMS75

BMS76

BMS77

BMS78

BMS79

BMS80

BMS81

Structural Properties of Two Brick-Concrete-Block Wall Constructions and a Concrete-Block Wall Construction Sponsored by the National Concrete Masonry Association

Plastic Calking Materials

Performance Test of Floor Coverings for Use in Low-Cost Housing: Part 1...

Stability of Sheathing Papers as Determined by Accelerated Aging

Structural Properties of Wood-Frane Wall, Partition, Floor, and Roof Constructions With "Red Stripe" Lath Sponsored by The Weston Paper and Manufacturing $\mathrm{Co}$

Structural Properties of "Palisade Homes" Constructions for Walls, Partitions, and Floors, Sponsored by Palisade Homes

Structural Properties of Two "Dunstone" Wall Constructions Sponsored by the W. E. Dunn Manufaoturing Co _........................

Structural Properties of a Wall Construction of "Pfeifer Units" Sponsored by the

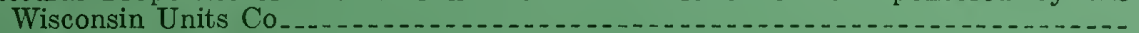

Structural Properties of a Wall Construction of "Irnap Concrete Wall Units" Sponsored by Knap America, Inc._.

Effect of Heating and Cooling on the Permeability of Masonry Walls

Structural Properties of Wood-Frame Wall and Partition Construction with "Celotex" Insulating Boards Sponsored by The Celotex Corporation . . .

Performance Test of Floor Coverings for Use in Low-Cost Housing: Part 2 -

Surface Treatment of Steel Prior to Painting-_-

Air Infiltration Through Windows _.....

Structural Properties of "Scot-Bilt" Prefabricated Sheet-Steel Constructions for Walls, Floors, and Roofs Sponsored by The Globe-Wernicke Co

Structural Properties of Prefabricated Wood-Frame Constructions for Walls, Par-

titions, and Floors Sponsored by Anierican Houses, Inc Sponsored by the Homasote Co

Metallic Roofing for Low-Cost House Construction

Stability of Fiber Building Boards as Determined by Accelerated Aging........... 10

Structural Properties of "Tilecrete Type A" Floor Construction Sponsored by the Tilecrete Co

Effect of Ceiling Insulation Únon Summer Comfort

Structural Properties of a Masonry Wall Construction of "Munlock Dry Wall Brick" Sponsored by the Munlock Engineering Co

Effect of Soot on the Rating of an Oil-Fired Heating Boiler

Effects of Wetting and Drying on the Permeability of Masonry Walls

A Survey of Humidities in Residences

Roofing in the United States-Results of a Questionnaire

Strength of Soft-Soldered Joints in Copper Tubing

Properties of Adhesives for Floor Coverings

Strength, Absorption, and Resistance to Laboratory Freezing and Thawing of Building

Bricks Produced in the United States . .

Structural Properties of Two Nonreinforced Monolithic Concrete Wall Constructions.- $10 \phi$

Structural Properties of a Precast Joist Concrete Floor Construction Sponsored by the Portland Cement Association

Moisture Condensation in Building Walls

Solar Heating of Various Surfaces W.........

Methods of Estimating Loads in Plumbing Systems

Plumbing Manual _..

Structural Properties of "Mu-Steel" Prefabricated Sheet-Steel Constructions for Walls, Partitions, Floors, and Roofs, Sponsored by Herman A. Mugler

Performance Tcst for Floor Coverings for Use in Low-Cost Housing: Part 3

Stability of Fiber Sheathing Boards as Determined by Accelcrated Aging-_...-

Asphalt-Prepared Roll Roofings and Shingles _.

Fire Tests of Wood-and Metal-Framed Partitions

Structural Properties of "Precision-Built, Jr." Prefabricated Wood-Frame Wall Construction Sponsored by the Homasote Co

Indentation Characteristics of Floor Coverings.

Structural and Hcat-Transfer Properties of "U. S. S. Panelbilt" Prefabricated SheetSteel Constructions for Walls, Partitions, and Roofs Sponsored by the Tennessee Coal, Iron \& Railroad Co

Survey of Roofing Materials in the North Central States

Effect of Outdoor Exposure on the Water Permeability of Masonry Walls

Properties and Performance of Fiber Tile Boards _...

Structural, Heat-Transfer, and Water-Permeability Properties of Five Earth-Wail Constructions

Water-Distributing Systems for Buildings

Performance Test of Floor Coverings for Use in Low-Cost Housing: Part 4

Field Inspectors' Check List for Building Constructions (cloth cover, 5 x 73/2 inches) -- $30 \phi$

-Out of print.

[List continued on cover page rv] 


\section{BUILDING MATERIALS AND STRUCTURES REPORTS}

[Continued from cover page III]

BMS82

BMS83

BMS84

BMS85

BMS86

BMS87

BMS88

BMS89

BMS90

BMS91

BMS92

BMS93

BMS94

BMS95

BMS96

BMS97

BMS98

BMS99

BMS100

BMS101

BMS102

BMS103

BMS104

BMS105

BMS106

BMS107

BMS108

BMS109

BMS110

BMS111

BMS112

BMS113

BMS114

BMS115

BMS116

BMS117

BMS118

BMS119

BMS120

BMS121

BMS122

BMS123

BMS124
Water Permeability of Walls Built of Masonry Units

Strength of Sleeve Joints in Copper Tubing Made With Various Lead-Base Solders 15

Survey of Roofing Materials in the South Central States

Dimensional Changes of Floor Coverings With Changes in Relative Humidity and

Structural, Heat-Transfer, and Water-Permeability Properties of "Speedbrik"; Wall Construction Sponsored by the General Shale Products Corporation -..........-

A Method for Developing Specifications for Building Construction-Report of Subcommittee on Specifications of the Central Housing Committee on Research, Design, and Construction

Recommended Building Code Requirements for New Dwelling Construction With Special Reference to War Housing

Structural Properties of "Precision-Built, Jr." (Second Construction) Prefabricated Wood-Frame Wall Construction Sponsored by the Homasote Co _......... Structural Properties of "PHC" Prefabricated Wood-Frame Constructions for. Walls, Floors, and Roofs Sponsored by the $\mathrm{PHC}$ Housing Corporation........ A Glossary of Housing Terms Fire-Resistance Classifications of Building Constructions - Accumulation of Moisture in Walls of Frame Construction During Winter Exposure.Water Permeability and Weathering Resistance of Stucco-Faced, Gunite-Faced, and "Knap Concrete-Unit" Walls _. Res. Tests of Cement-Water Paints and Other Waterproofings for Unit-Masonry Walls.-:Properties of a Porous Concrete of Cement and Uniform-Sized Gravel..... Experimental Dry-Wall Construction With Fiber Insulating Board . . Physical Properties of Terrazzo Aggregates Structural and Heat-Transfer Properties of "Multiple Box-Girder Plywood Panels" for Walls, Floors, and Roofs

Relative Slipperiness of Floor and Deck Surfaces Strength and Resistance to Corrosion of Ties for Cavity Walls Painting Steel

Measurements of Heat Losses From Slab Floors

Structural Properties of Prefabricated Plywood Lightweight Constructions for Walls, Partitions, Floors, and Roofs Sponsored by the Douglas Fir Plywood Association-

Paint Manual with particular reference to Federal Specifications. Laboratory Observations of Condensation in Wall Specimens. Building Code Requirements for New Dwelling Construction Temperature Distribution in a Test Bungalow With Various Heating Devices.-... $15 \phi$ Strength of Houses: Application of Engineering Principles to Structural Design Paints for Exterior Masonry Walls . Performance of a Coal-Fired Boiler Converted to Oil Properties of Some Lightweight-Aggregate Concretes With and Without an Airentraining Admixture

Fire Resistance of Structural Clay Tile Partitions Temperature in a Test Bungalow With Some Radiant and Jacketed Space Heaters.-. A Study of a Baseboard Convector Heating System in a Test Bungalow

Preparation and Revision of Building Codes . - . . . Fire Resistance of Walls of Lightweight Aggregate Concrete Masonry Units Stack Venting of Plumbing Fixtures Wet Venting of Plumbing Fixtures Fire Resistance of Walls of Gravel-Aggregate Concrete Masonry Units. Investigation of Failures of White-Coat Plasters.

Physical Properties of Some Samples of Asbestos-Cement Siding Fire Tests of Wood-Framed Walls and Partitions With Asbestos-Cement Facings.-..Fire Tests of Steel Columns Protected With Siliceous Aggregate Concrete.

-Out of print.

* In Press. 